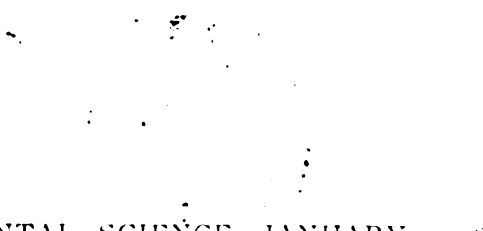

JOURNAL OF MENTAL SCIEÁCE, JANUARY, I1)2

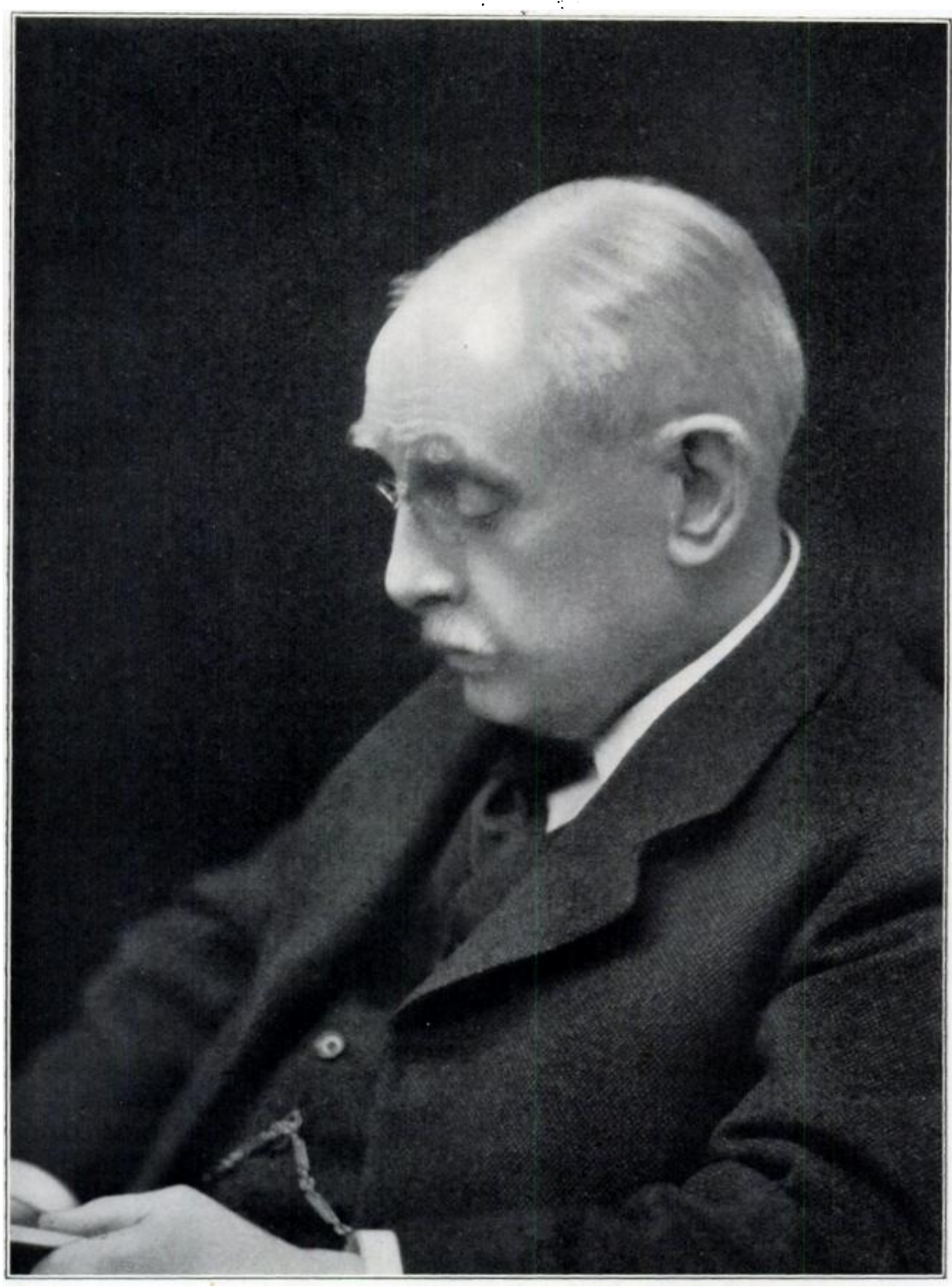

Sir Horatio Bryax Donkin, M.A., M.D.Oxon., F.R.C.P.

Born February I, $18+5$.

Honorary Member since 1911.

Died July $26,1927$. 


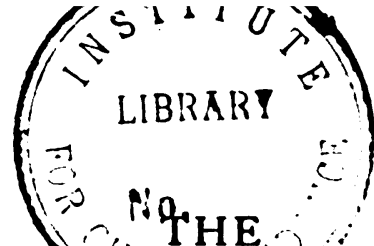 \\ JOURNAL OF AUEAL SCIENCE \\ [Published by Authority of the Royal Medico-Psychological Association.]}

\section{No. $304\left[\begin{array}{c}\text { NRW strins } \\ \text { No. 268. }\end{array}\right]$ JANUARY, $1928 . \quad$ Vor. LXXIV.}

\section{SIR HORATIO BRYAN DONKIN, M.A., M.D.OxON., F.R.C.P.}

ThE roll of illustrious honorary members of the Royal MedicoPsychological Association suffered a severe loss by the death of Sir Bryan Donkin on July 26, 1927, and the Prison Service was left to mourn a distinguished member of a past Board of Commissioners and an eminent civil servant.

He was the eldest son of the late Bryan Donkin, C.E., and was born on February I, 1845. He was educated at Blackheath Proprietary School, and entered Queen's College, Oxford, in 1863 with an open scholarship. He gained a first class in Greats, graduated B.A., and took the degree of M.A. in 1871 . His original intention was to practise law, and he was called by the Inner Temple in 1868 , but later decided to follow the profession of medicine, and entered St. Thomas's Hospital, and qualified as M.R.C.S.Eng. and M.B. Oxford in 1873. He was elected a Fellow of the Royal College of Physicians in I880, and took the degree of M.D. at Oxford in 1893. He served for some time as Physician to the Westminster Hospital, and to the East London Hospital for Children, and as Lecturer on Medicine at Westminster Hospital and at the London School of Medicine for Women. He was also an Examiner in Medicine for the Conjoint Examining Board in England, and a Consulting Physician to Westminster Hospital, the East London Hospital for Children, and the King George (R.A.M.C.) Hospital. He was Harveian Orator at the Royal College of Physicians in 1910, taking as his subject "The Inheritance of Mental Characters."

In 1898 Donkin was appointed by the King to be one of His Majesty's Commissioners of Prisons and a Director of Convict Prisons. He became a member of the Royal Commission on the Care and Control of the Feebleminded which commenced its labours in 1904, and of the Departmental Committee of 1908 on the 
Inebriates Acts and Treatment of Inebriety. He retired from the Prison Commission on attaining the age-limit in 1910, but still remained in touch with prison administration as a Director of Convict Prisons, as a member of the Advisory Committee to the Secretary of State at Camp Hill Preventive Detention Prison, and as a member of the Visiting Committee at Borstal Institutions. He received the honour of Knighthood in $191 \mathrm{I}$ in recognition of his public services.

It is almost inevitable that a man who reaches his eighty-second year will leave at his death no witness able to record his earlier hopes and fears, his sympathies and antipathies, his ambitions or manner of work and his later interests and achievements. So with Donkin, it is left to one who knew him only during and after his official life to write these words. There is, however, reason to believe that he regarded this period as the most important of his career.

Donkin entered the Prison Service, and became the first medical representative, a stranger, on the Board of Commissioners, but he gained the confidence and affection of his co-workers from the commencement of their association, and the passing years added to his influence. His equanimity and wide experience of men and affairs, combined with wisdom and quiet courage, clear vision and tenacity of purpose made him a valuable counsellor. A student throughout a long life, it was perhaps as such that he appealed most strongly to the prison medical officers; their difficulties became his, and their anxieties attracted his whole-hearted support. He was ever ready to encourage research and individual effort, and gave his advice freely.

In November, 192I, Donkin contributed to the British Medical Fournal a review on the English Prison System written by Sir Evelyn Ruggles-Brise, late Chairman of the Prison Commission. He took this opportunity to make certain observations on the medical branch of the service. He first quoted the author's statement that "The medical care of criminals in this country is as exact and patient and considerate as can be secured by an able humane and untiring medical staff," and then himself remarked: "It may be said here that especially during the last dozen years or so the work of the medical officers of our prisons has been very onerous, owing not only to the rapid growth of medical knowledge from the latter part of the last century up to now, but also to various incidental circumstances. Within this period the whole question of prison diets has been re-organized on a scientific basis, and from time to time modified under the techincal supervision of successive medical inspectors, especially by Sir Herbert Smalley and Dr. Treadwell, late Medical Commissioners of Prisons. The difficulty 
of this task was greatly increased by the necessary changes introduced under the stress of war-time, when there was much scarcity of the staple foodstuffs. ${ }^{*}$ Nor must we forget the exceptionally grave responsibility thrown by the Government on the prison medical officer, both before the war and later, during the frequent and protracted spells of "hunger-striking " on the part of various classes of prisoners commonly described as "political." Medical officers were charged with the extraordinarily harassing obligation of reporting from time to time whether such persons were physically and mentally fit for further detention. I venture to hope, as I have long contended, that in case of further occurrences of this kind the whole responsibility of preserving the life of such persons will be cast on their own friends and advisers, to whom all possible facilities and means should be provided by authority."

Donkin is concerned here clearly with the responsibility placed upon the medical officers, and I have no reason to believe that he objected to tube-feeding as such, or that he held the extreme view of Dr. Maudsley, who, it will be remembered, regarded the forcible feeding of insane persons to be degrading alike to the doctor and to the patient.

Those of us who look back upon his work as Commissioner have come to regard Donkin as the first co-ordinating force of modern medical progress in our prisons. He was fortunate to find, on taking up his official duties, men peculiarly fitted in the three main spheres of prison work with whom to co-operate. As a colleague at the Home Office, Dr. (now Sir) Herbert Smalley, who later became Commissioner, was Medical Inspector, and his long and intimate knowledge of prison problems was placed unreservedly at Donkin's disposal. Dr. O. F. N. Treadwell, who also became a Prison Commissioner, was carrying out his duties as medical officer in the convict prisons with prevision, and the late Dr. James Scott was recognized in the criminal courts as a reliable psychiatrist. These men, standing four-square, advanced the medical view of criminal problems to a position which it had not previously occupied officially, and from which further advancement was possible. They were pioneers, and the medical officers of the present day gratefully acknowledge their labours. It has seemed right to refer to their joint influence in an appreciation of Sir Bryan's own work, since he himself so constantly referred in generous terms to the work done by others. And it may be remembered that when Scott died some three years ago, Donkin, in a letter to The Times, recorded his appreciation of the erudition and services of that admirable expert-witness.

* A later Departmental Committee on Prison Diets sat during 1924-25 under the Chairmanship of Dr. G. B. Griffiths, Medical Commissioner. 
On attaining his Commissionership Donkin directed his attention to the intricate administrative problems arising from the association of abnormal mental states and criminal conduct, and his writings on criminal matters are concerned mainly with the wide application of technical knowledge and scientific thought to their elucidation. He, however, always recognized the necessity for clinical research in this direction, and insisted upon the importance of the study of individual cases. He expressed the opinion that even the most comprehensive generalization concerning convicted criminals was not likely to be of much positive value in the study or treatment of individuals, since the differences of observable characters in criminals and law-abiding men were so great.

The scientific investigation of those who offend against the criminal law can be carried out on similar lines to those used in the study of physical and mental disease. The two usual methods of approach offer themselves. The condition, whether normal or abnormal, may be examined clinically, and in detail, or investigation may be directed to ascertain the correlation between antisocial conduct and the influence of environment and heredity. I have already said that insufficient knowledge concerning Donkin's earlier years prevents the formation of any conclusion as to their influence on his later work; but there can be no doubt that during his Commissionership, and after, the work which appealed to him strongly was the study of the incidence of crime and its. factors of heredity and environment. It must be borne in mind, however, that his position as an administrator facilitated his work in this direction, and that systematic clinical research might be at times officially inopportune. It may well be that he chose the work nearest to hand, and this view receives some support when it is remembered that he was a keen and observant clinician throughout his career.

Notable advance in prison administration has taken place since Donkin joined the Service. In this he took a full share. Much remains, and probably always will remain, to engage the attention of future workers. In the sphere of mental disorder alone, and its association with delinquent conduct, we must expect that psychological and criminal problems will perplex both scientists and administrators for many years to come. No one appreciated this. more fully than Donkin, whose administrative work was marked by courage, foresight, moderation and sympathy. He realized that lasting progress might be delayed if attempts were made to forceits too rapid growth, particularly in matters concerning social hygiene; and that not only was it necessary to be convinced oneself of the correct line of advance, but that it was equally important: 
to convince others, who might be less assured that alterations were desirable.

This is not the time, neither is it the place, to enter into any particular account of the changes in the medical work of prisons that have arisen since Donkin joined the Prison Commission. It may be permissible to observe, however, that with criminals, as with the insane, incurable ineffectives remain a burden to the community, and that the most hopeful field of work lies in prevention. To this end modern medical efforts are directed to the early diagnosis of abnormal mental states associated with delinquency; to the unravelling, as far as possible, of the complex causes of individual crimes by psychological investigations, assisted by reports from voluntary social workers and home visitors; and by efforts to correct and adjust the offender at the beginning of his anti-social career.

Donkin agreed that the criminal did not necessarily differ essentially in his mental make-up from the law-abiding subject. He stated in his lectures on "Mental Defect and Criminal Conduct," delivered at the Maudsley Hospital in 1920, that he had long been convinced in common with other observers that all human beings were potential criminals, and that a large number of men and women committed crime in the sense of wilfully injuring society for their own individual purpose, whether or not they were detected in breaking, or even broke, any existing law. He added that the study of criminals was an integral part of the study of man, and of human psychology especially ; but that the indefinite nature of the differences that had as yet been established between criminals and lawabiding men in the mass, seemed to him to point away from the prospect of establishing anything like a special and clear-cut body of knowledge, which would merit the name of a "science" of criminology. In this view Donkin had been opposed previously by Charles Goring, and readers of this Journal may remember the controversy which took place between them in its pages some years ago. It arose out of certain statements made by Goring in his monumental statistical study, The English Convict, published officially in 1913, and was terminated by his sudden and everlamented death. Space prevents me from reminding the reader of the details of their respective points of view; suffice it to say that Goring held criminology to be a "Science critical of the ideas by which conduct is being regulated."

Donkin readily engaged in controversy, but he never bore any ill-will towards his disputant. The joy of strenuous mental combat was his, and he delighted in the thrusts and parries of his adversary, with whom he was not infrequently on terms of mutual respect and 
SIR HORATIO BRYAN DONKIN, [Jan.,

goodwill. This was peculiarly the case in the personal relations of Donkin and Goring. Both were men of brilliant intellect, and both possessed rare personal charm.

Donkin considered the mental make-up of all men, whether lawbreakers or law-abiders, depended upon inborn capacities, or possibilities of development, as well as on the multiform agencies from without, which act upon the germinal material and may influence its development. And he concluded from his studies that the various mental qualities of man could not be considered for the purpose of any investigation as simply constitutional or inborn without taking account of the external influences on their actual development. Difficult as it must be to assess with any precision the proportionate influence of the two necessary factors of heredity and environment in the development of the minds of normal men, no one accustomed to research among criminals will gainsay that in their case the assessment will be surrounded with even more difficulties, and Donkin considered it impracticable. He believed that wherever the truth might lie it was at present impossible to deal with human beings in the manner suggested by the most advanced adherents of Eugenic doctrines. He regarded with respect the legal, medical and administrative difficulties which would result from the adoption in this country of sterilization laws; and was convinced that no practicable measure could possibly cut off the supply of mental defectives, however much it might limit this supply, since all grades of marked defect frequently appear, and apparently de novo, in families in whom it is impossible to trace any near or distant relative similarly affected.

Some of us have thought that Donkin's original estimate of the amount of mental deficiency in the prison population was too high. In a conference at Birmingham he said, "The bald statement may be accepted that the weak-minded amount to between 10 and $15 \%$ of the total number of persons committed to prison; the true maximum is probably higher than this." And later he stated, "Owing to their inherited incapacities and surroundings a large number of mental defectives tend to become criminals, and the considerable proportion, even $20 \%$ of so-called criminals or lawbreakers, are demonstrably mentally defective." This opinion he formed as a result of his official experience, and as a member of the Royal Commission on the Care and Control of the Feeble-minded, and it was expressed before the Mental Deficiency Bill of 1913 became law. There is reason to believe, however, that these views were modified in later years, for in the Maudsley Lectures referred to above he recorded the fact that of 475 prisoners who, as habitual criminals, were sentenced to preventive detention, and among whom 
a high incidence of mental defect might be assumed, II and no more were certifiable under the Mental Deficiency Act. And in a letter Donkin in 1925 referred me to these lectures for his views on the incidence of mental defect and crime. These figures, it will be observed, are more in agreement with those obtained by recent workers in our prisons, and Donkin recognized their significance in so far as they indicated that a special group of recidivist convicts, many of whom had spent more than half their lives in prison, showed no higher incidence of recognized mental defect than the less selected mass of prisoners in general.

The embarrassments resulting from the wording of the Mental Deficiency Act, 1913, soon became apparent in prison administration, for it was found impossible to relate the defect to early age in the majority of adult defectives. It must be acknowledged with gratitude that this difficulty is now largely overcome in adolescent cases by the help of educational authorities and voluntary associations. But Donkin was led to consider that the mere description of the various grades of mental defect should not have been converted into a statutory definition, nor incorporated in the required certificate. He regarded the essence of the certificate in cases of lunacy and mental deficiency to be reasoned opinion, and probably the majority of those engaged in certification will endorse his view. This was perhaps one reason why he so strongly desired the union of the Lunacy Acts with the Mental Deficiency Act. It does seem, however, to some of us who have worked in the criminal courts that if such union came to pass it might create difficulties, perhaps not less formidable than those which it attempted to solve.

Donkin's interest in the subject of criminal responsibility made him peculiarly fitted to write the introduction to Mercier's book, Crime and Criminals. He considered that the conception of responsibility nominally accepted in law required modification, and that degrees of responsibility should be decided in persons charged with crime. He agreed with the recommendation of the Joint Committec appointed to report on the matter, and adopted at the General Meeting of the British Medical Association in 1915, that in order to incur full responsibility a man must not only know, but also appreciate the nature and quality of his act, and also know and appreciate the circumstances in which it was done. $\mathrm{He}$ insisted that the only way to discover whether a criminal did know and appreciate the circumstances was to study his actions, or in other words his conduct in those circumstances. And he considered that a full regard for acts done, and all the circumstances in which they were done, would often be of great assistance in cases of special difficulty, and would enable medical witnesses to show 
that, although the accused knew in a limited sense of the word that the act he did was wrong, he yet did not appreciate all the circumstances and consequences of his act, and thus misconceived and under-estimated its wrongness. He agreed with Mercier that the turpitude of the criminal is to be judged by the intention with which he performs an act. That if he intends and tries to murder a man and does not succeed he should be hanged; and that if he intends to kill a dog and by mistake kills a man he should be punished only for killing the dog. And as the intention determines turpitude, so it ought to determine the nature of the crime and punishment.

No account of Donkin's views on psychological problems would be complete without a brief reference to his considered opinion regarding psycho-analytic theory and practice, to which he was actively hostile. He believed that they were unscientifically grounded upon deductions from unwarranted assumptions and false premises. He held that the protest of most psycho-analysts that no one is competent, or has a right to discuss the grounds, or the practice of psycho-analysis, unless he has himself carried out or been personally subjected to psycho-analytical examination, was fundamentally unsound, and if accepted, entirely vitiated the inquirer's judgment. He regarded the failure of psychoanalysts to report or publish their successes in such detail as is required by medical readers, or medical or other societies, whereat discussion and study are invited, indicated their unwillingness to subject their results to informed criticism. And he deplored the tendency of some medical men to acquiesce in the treatment of patients suffering from mental disorders by psycho-analysts who lacked medical training and qualification.

It would be unfair to attribute Donkin's antagonism to the conservatism of old age, and equally unfair to assume that his disapproval biased his judgment of the value of his opponent's arguments. His disapproval was rather the result of his belief that the methods of science were the only ones that he could trust, and that other methods led away from truth to speculation and confusion. He was, moreover, acquainted with patients who had suffered grievous injury at the hands of practitioners of psychoanalysis, and was apprehensive lest similar results befell others. $\mathrm{He}$ studied the literature of the subject with critical interest, and the discussion on psycho-analysis and its development held at the annual meeting of the Association in London on July 15, 1926, was one of the last at which he attended.

Donkin's interest in venereal disease was becoming in one who was ultimately responsible officially for the health of several thousand prisoners of both sexes, many of whom were peculiarly subject to 
venereal disease by their manner of living. It will be remembered that in 1913 a Royal Commission was appointed to inquire into the effects of venereal diseases and the best means of combating them. In the same year the National Council for Combating Venereal Disease was created. The Report of the Royal Commission was published in 1916, and as a result of the combined efforts of the two bodies an Act of Parliament was ultimately passed, which made provision for the better and earlier treatment of already infected persons. Donkin was a member of the National Council, and has described how its members advocated at first "early treatment" of persons already infected, and that as time and more or less open discussion went on the term "early preventive treatment" was introduced. But he became dissatisfied with the Council's programme, and resigned from that body because it vigorously opposed facilities for persons who ran the risk of infection to provide themselves with disinfectants which could be used immediately after transgressing.

He wrote subsequently a letter to the Times, in January, 1917, urging preventive measures, and shortly afterwards joined forces with his old friend, Dr. Archdall Reid, who had been directing practical efforts to diminish venereal disease among the large number of soldiers who were under his medical charge. In his book on the Prevention of Venereal Disease, Sir Archdall Reid pays a large-hearted tribute to Donkin's co-operation. He describes his letter to the Times as "fateful," and adds that "since then the history of the movement for the medical prevention of venereal disease is mainly the history of his labours on its behalf." Sir Archdall Reid describes how they were able to give each other mutual support. Donkin was in a position to influence public opinion, especially the opinion of leading members of the profession, and Reid was able to furnish an object-lesson in immediate disinfection.

The Report of the Royal Commission led to the formation of the Society for the Prevention of Venereal Disease with a prophylactic policy, and Donkin and Sir Archdall Reid joined its long list of distinguished supporters by invitation. In sending a representative to attend his funeral the Society gracefully recognized Donkin's services to a common cause.

The first contribution to medical literature which I am able to trace to Donkin is a "Commentary on 105 Cases of Chorea " published in the Westminster Hospital Reports in 1885 . He also published a book on Diseases of Childhood in 1893 . He wrote the article on "Hysteria" in Tuke's Diclionary of Psychological Medicine, representing the English point of view at that time; this was accompanied by an article on hysteria in the same volume by 
Charcot and Marie representing the French standpoint, and both English and French descriptions contain much of interest for the student of to-day. Among later contributions were "Notes on Mental Defect in Criminals," "The Factors of Criminal Actions," "Occasional Notes on the Mental Deficiency Act," and the obituary notice of Charles Mercier, all of which appeared in this Journal. He contributed to Bed-Rock, of which review he was at one time coeditor, articles on "The Mental Deficiency Bill and its Critics," "Some Thoughts on the State Punishment of Crime," "A Note on Legislation for the Control of the Feeble-minded," and on "Science and Spiritualism." His lectures on "Mental Defect and Criminal Conduct" were reprinted in the Lancet. He wrote in the Nineteenth Century and After on "The Fight against Venereal Infection," and also wrote an introduction to Dr. McBride's book, PsychoAnalysts Analysed, to Sir Archdall Reid's work on the The Prevention of Venereal Disease, and, as already mentioned, to Mercier's book, Crime and Criminals.

Donkin was an independent thinker, and a fearless, painstaking and scholarly writer. In some of his literary work one seems to detect his thoughts even as they shaped themselves in his mind in orderly sequence. But he was a precisian, and sometimes one can believe that his pen halted for a moment whilst he searched through the storehouse of his learning for the only word that fitted his purpose. The finished polish of the honest workman was his, and he eschewed artificial effects. His obituary notice of Mercier was an admirable piece of writing, a sincere record of the dead man's character and work, traced with a firm yet delicate touch, and formed a notable offering to their friendship of thirty-five years.

Donkin never forgot his Classics, and was extremely well read in English and French literature. He retained a loyal affection for his old University, and had the good fortune to read the Greats School there, and fully appreciated in after life all that he owed to his earlier studies in philosophy. On him were stamped all its traditional works, the alertness of mind, the fastidiousness of taste, the dislike of what is vulgar and illiberal, above all the love of learning for its own sake. Few things delighted him more than to hear news of the Oxford of to-day, and compare it with the Oxford of the 'sixties when he read essays to Jowett, and had been the special pupil of Walter Pater. Even more did he love to go back there and re-visit his old tutor, Dr. Mograth, who still presides over the College to which more than sixty years ago he first welcomed Donkin as an undergraduate.

An old friend of Donkin's writes : "Many of his contemporaries have made more noise in the world; many have had more than he 
of the qualities that make men famous and admired. But in the qualities which make men happy in their own lives and a source of happiness to others, in good sense and good manners, using manners in the older and nobler meaning of the word, Bryan Donkin was not and will not be surpassed."

His sincerity, sympathy, learning and modesty won him friends and admirers far beyond the circle of his own profession, and it was to help him in raising funds for the East London Hospital that one of them, W. E. Henley, first came to publish verse. He was intolerant of advertisement, chicanery, charlatanism and loose thinking; he only spoke and wrote that which he believed to be true, and was always ready to unsheath his sword in the cause of truth as he saw it. The friend referred to above notes that " in an age so given to specialization that scientific and humane learning are regarded as almost antagonistic, it ought not to be forgotten how admirably Donkin contrived to combine them. Like the great men of the early days of science he would not submit to any such unnatural separation." He was, in truth, not only a learned, but a humane and sensitive man, and peculiarly responsive to sympathy; some two years before his death the writer congratulated him upon a certain course of action he had taken, and his expression of thanks remains a living memory.

During his earlier years Donkin found outdoor relaxation in riding and rowing, of which he was very fond, but he cultivated no hobbies or outdoor pursuits in later life. He retained his interest in medical progress and general affairs to the end, and visited his successors at the Home Office to within a few months of his death. He believed that mental alertness would compensate for such physical inactivities as the passing years might inflict, but he was singularly free from the disabilities of age, and was engaged in preparing material for publication in this Journal when struck down with hemiplegia, which ended fatally within a few days.

Sir Bryan married, in I888, Auguste Margaretha Elisabeth, daughter of Conte di Langhi of Cracow. There were no children of the marriage, and her death in 1919 was a severe blow to him. When he married in 1923 an old friend of the family, Mrs. Marie Louise Bates, daughter of the late William Reston, of North Carolina, and widow of Isaac Bates, of Belfast, his friends rejoiced, for this gracious lady gave him the intellectual companionship which the advancing years, and the deprivation of outlived friends, made increasingly difficult for him to obtain.

A last word. Donkin had considered his religious position when at Oxford with the systematic deliberation which characterized him. He consulted a number of spiritual advisers, among them 
Dean Liddon and a Catholic priest. In the end, as not infrequently happens in such cases, he found himself unable to accept any system of dogmatic religion. He, however, retained an interest in the affairs of the Church of England, and stoutly as he maintained his own views, respected those of others. He believed that beyond man's finite understanding there is an Infinite Purpose. As he surveyed the future untiring and confident, he looked back upon a life of high endeavour and solid achievement, honoured by his own profession; honoured, too, by those others with whom he had laboured for so many years. Need man wish more? Need more be said?

W. Norwood EAst.

\section{Part I.-Original Articles.}

The Beattic Smith Lectures on Insanity for 1926.* By Richard J. A. Berry, M.D., F.R.C.S., F.R.S.Edin., Professor of Anatomy, including Histology, in the University of Melbourne; Honorary Psychiatrist to the Children's Hospital, Melbourne; Honorary Consulting Psychiatrist to the Melbourne Hospital, and Member of the Royal Medico-Psychological Association.

Lecture I.-The Principles of Neurology.

THE nervous system of all vertebrates is built up of long conducting, specialized cells, termed neurons. In order to function, these neurons, or nerve-cells, must be linked together in chains or arcs. Each neuron in the chain or arc is structurally separated from other neurons by a break termed a synapse. The structural elements of a neuronic arc are, therefore, as follows :

I. A sensitive receiving organ-the receptor or sense-organ.

2. A centrally conducting receptor bipolar neuron.

3. One or more short connector or internuncial neurons.

4. A peripherally conducting effector multipolar neuron.

5. An effector apparatus-for example, a muscle or a gland.

The phenomena of the nervous system are much more easily understood if the terms "receptor" and "effector" are uniformly utilized instead of the older " sensory or afferent" and " motor or efferent." In fact, the older terms are frequently quite inaccurate,

* The late Dr. W. Beattie Smith, of Melbourne, in the expressed belief that " both the Profession and the Public were in need of education on the nationally important problem of Insanity," bequeathed to the University of Melbourne the necessary funds for the establishment of an annual course of lectures. The 1926 series, in the regrettable absence through illness of Professor Sir John Macpherson, were delivered by Professor Berry, in December, 1926, in Melbourne, and in April-May, 1927, in New York, U.S.A., at the Cornell University. 